\title{
Research on Measures to Promote the Realization of Chinese Dream by the United Front Ideology of Xi Jinping
}

\author{
Ai Jian \\ Xi'an Peihua University, Xi’an, Shaanxi, 710125
}

Keywords: united front; promote; Chinese Dream

\begin{abstract}
Based on the analysis, generalization and sorting of related literature, this paper demonstrates that the united front is an effective weapon for realizing the Chinese Dream, and Chinese Dream is the spiritual force for the realization of the united front. These two are closely related and mutually promoted at the same direction. In the new era, it is necessary to firmly exert the weapon role of the united front and its unique function in realizing Chinese Dream, form strong joint force to promote the Chinese Dream and realize the Chinese Dream of the great rejuvenation of the Chinese nation
\end{abstract}

\section{Introduction to the Unified Front Ideology of Xi Jinping}

Since the 18th National Congress of the Communist Party of China, the leadership of the Party Central Committee with Comrade Xi Jinping as the core has led the people of all nationalities in the country to raise the flag and determine the direction, plan the structure, overcome difficulties, strengthen the foundation, open up a new realm of governing the country, and create a new situation for the cause development of the party and the state. In the new practice of governance, Xi Jinping, with extraordinarily theoretical courage and political wisdom, grasps the general trend of the times, and delivers a series of important speeches on reform and development stability, domestic affairs, foreign affairs and national defense, the ruling of the party, state and military, forming a series of new ideology and new measures of governance, further enriching and developing scientific theories of the party, and establishing Xi Jinping's thought on socialism with Chinese characteristics for a new era. The unified front ideology is an important part of Xi Jinping's thought on socialism with Chinese characteristics for a new era. Centered with the Two-Centenary struggling goal and the general task of socialism with Chinese characteristics, which is the realization of socialism modernization and the implementation of Chinese Dream of the great rejuvenation of the Chinese nation, it answers the questions, such as whether the united front is needed in new era, what kind of united front is needed, how to consolidate and develop the united front, and what the policies in all fields in new era include, [1] and it is the is the latest theoretical achievement of the localization of Marxism in China.

\section{The united front is an effective weapon for realizing the Chinese Dream}

To advance the Chinese Dream of the great rejuvenation of Chinese nation is the great strategic goal and the theme pursued eternally of the party in new era. Since the $18^{\text {th }}$ National Congress of the CPC, $\mathrm{Xi}$ jinping puts forward that Chinese Dream of the great rejuvenation of Chinese nation is the greatest common divisor to unite all Chinese people at home and abroad. In the report of the $19^{\text {th }}$ National Congress of the CPC, "Chinese nation" was mentioned 43 times, "great" mentioned 75 times, "rejuvenation” 32 times, and "Chinese Dream” 13 times. From the digital interpretation, it can be seen that since General Secretary Xi Jinping has served as the party and state leaders, all his thoughts, policies, and measures have been committed to the realization of the Chinese Dream of the great rejuvenation of the Chinese nation.

The unified front ideology is an important component of Marxism theory, and effective weapon for the victory of Chinese revolution, construction and reform cause. In broad sense, the "united front" refers to the political alliance formed by different classes, social stratification, political power 
or groups, under certain historical conditions, to achieve common interests and goals. The united front at present stage refers to the united front organized and led by the proletariat and its political parties under the guidance of Marxist theory. [2] The united front of Xi Jinping is the localization of the Marxist united front theory in China, the continuation and innovation of Mao Zedong and Deng Xiaoping united front ideology, an important part of $\mathrm{Xi}$ Jinping's socialism with Chinese characteristics for a new era, and the general task to accelerate the completion of the socialism with Chinese characteristics, the important effective weapon for realizing the socialist modernization and the great rejuvenation of the Chinese nation, which must inevitably serve the Chinese Dream of the great rejuvenation of Chinese nation. Xi Jinping's ideology of united front is no exception.

General Secretary Xi Jinping pointed out that the realization of the Chinese Dream needs to bring together countless individuals to make joint efforts to the same place, which requires the party to unite all forces that can be united, unite the people of all nationalities, unify our thoughts, and build a Chinese Dream together. In May 2015, he clearly pointed out at the United Front Work Department of CPC Central Committee Conference, "The united front is an effective weapon for the victory of revolution, construction, and reform cause. It is an effective weapon for building a well-off society in an all-round way, accelerating modernization, and realizing the Chinese Dream of the great rejuvenation of Chinese nation. In September of the same year, the first party internal regulations and laws on the united front work promulgated by the party, The Communist Party of China United Front Work Regulations (Trial), emphasized that the united front is an effective weapon to build a well-off society in an all-round way, accelerate the socialist modernization, and realize the Chinese Dream of the great rejuvenation of Chinese nation. [3] The essence of the united front is great unity and great coalition. The united front is to link the "dream-seekers" who realize the great rejuvenation of Chinese nation through the value function of unity and cooperation, and gathering people's hearts and strength, through the integration of political resources, economic, cultural and social resources, so that the society can make joint efforts to promote the community consciousness of the great rejuvenation of the Chinese nation, thus laying a solid foundation for the realization of the Chinese Dream, providing Chinese Power (the great unity of the Chinese nation), the Chinese Spirit (the national spirit with patriotism as the core and the spirit of the time with reform and innovation as the core), the institutional guarantee of the Chinese Road and the important means of realizing the Chinese Dream. [4] The united front in new era is an effective weapon to mobilize the enthusiasm, initiative and creativity of the majority of "dream-seeker" members, to continuously enhance the common ideology for unity and struggle, to extend the Chinese Dream to all aspects of society, and to realize the great rejuvenation of the Chinese nation, and the historical choice, realistic choice, internal choice and inevitable choice to realize the Chinese Dream.

\section{The Chinese Dream is the spiritual force for the realization of the united front}

The essence of the Chinese Dream is the prosperity of the country, the rejuvenation of the nation, and the happiness of the people. It is the greatest consensus of the united front in the new era. It is to expand the development of the united front, highlight the contemporary value of the united front and measure the contemporary standard of the united front in the new era. It combines the pursuit of the country, the aspirations of the nation, and the expectations of the people. It is the common vision and historical mission of every Chinese people of all nationalities in the country and links with the dreams of the people of all countries in the world. [5] Each of us is a member of the "dream-seeker", the writer and practitioner of the Chinese Dream. The Chinese Dream has determined the goal of struggle for the united front in the new era, and found the fundamental interests of state prosperity, national rejuvenation, and people's happiness (the happiness of countless individuals), which is an important prerequisite for the continuous development and growth of the united front in the new era. Since the moment when the Chinese dream was put forward by General Secretary Xi in November 2012, it has generated a strong appeal, inspiration and cohesiveness with its strong patriotism, with its great inclusiveness, has closely linked the fate of individuals and nations to the country, has brought together the cadres and the masses, the public opinion, Hong Kong, Macao and Taiwan 
compatriots, overseas Chinese, and friendly personage in international society into a team of "dream-seeker", through the bond of the Chinese Dream, has become the spiritual banner and spiritual motivation for the new era to forge ahead in unity and open up the future, and has become a spiritual bond connecting the united front and the great rejuvenation of the Chinese nation. Therefore, since its introduction, the Chinese Dream has played the role of the united front in unifying ideology and uniting public mind. The united front in the new era is to consider promoting the Chinese Dream of the great rejuvenation of the Chinese nation as its value consensus in the new era so as to play its role. Therefore, the development of the united front in the new era cannot be separated from the Chinese Dream. The Chinese Dream is the spiritual force for the practice of the united front. The united front is the method and means for the practice of the Chinese Dream. The Chinese Dream has opened up a broad space for the development of the united front in the new era.

\section{To Implement the Unified Front Ideology of Xi Jinping and Promote the Chinese Dream of the great rejuvenation of Chinese nation}

The united front is an effective weapon for realizing the Chinese Dream, and Chinese Dream is the spiritual force for the realization of the united front. These two are closely related and mutually promoted at the same direction. In the report of the 19th National Congress of the CPC, General Secretary Xi pointed out that the main contradiction in the new era has changed, and the only way to solve the main contradiction in the current society is to mobilize the enthusiasm of all parties under the leadership of our Party, gather force, develop China, strengthen China, build China into a powerful country of socialist modernization, and realize the Chinese Dream of the great rejuvenation of Chinese nation. The united front in the new era is a united front that provides broad power support for the realization of the Chinese Dream. It is required to actively implement the unified front ideology of General Secretary Xi Jinping through various channels, construct a big pattern of the great united front in the new era, and promote the realization of the Chinese Dream of the rejuvenation of Chinese nation.

First of all, to do a good job in united front work in the new era to serve the Chines Dream of the great rejuvenation of the Chinese nation, it is necessary to adhere to the leadership of the Communist Party of China and build a pattern of great united front. The united front departments at all levels should take the lead and formulate the Strategic Plan for the Education and Training of the United Front, and organize, learn and publicize the contents, guidelines and policies of Xi Jinping's united front ideology in the new era. They shall take the lead to participate in the practice of the united front, take the lead in making friends, establish regular channels of communication, enhance political identity and common interests, further implement the united front work, integrate the resources of the united front, expand the scope of the united front, and strive for the broadest force of unity and joint cooperation, so as to promote the realization of the Chinese Dream.

Secondly, to carry out a series of publicity and practical activities to promote the Chinese Dream with the united front, to unite people's hearts and integrate strength. Practical activities around regional dream, industry dream, and personal dream shall me implemented with the united front. Event organizers can include government agencies or non-governmental organizations, etc.; activity objects can include members of democratic parties, non-party personage, non-party intellectuals, ethnic minorities, people in religious conscience, non-public ownership economic personage, members of emerging social strata, overseas students and returned Chinese people, Hong Kong compatriots, Macao compatriots, Taiwan compatriots and their relatives on the mainland, overseas Chinese, returned overseas Chinese and their relatives, and other people who need to be contacted and unified; [6] The content of activities can focus on the history of Chinese people's dream seeking in modern times, the scientific connotation and essence of the Chinese Dream, and the difficult problems that need to be solved in the process of advancing the Chinese Dream, to guide the Chinese Dream participants to build a Chinese Dream through practical activities; the activity process can improve the united front think tank platform construction, inspire the object of the united front, especially high-end talents at home and abroad, intellectuals, non-public enterprises and successful people, and new media practitioners, etc., around economic, political, cultural, social, 
and ecological key issues related to social development, stability, and construction (such as how to effectively implement the precise poverty alleviation and rural revitalization strategy), to carry out thematic activities or platform forums in various ways to contribute to the development of the government, enterprises, organizations, etc., or participate in social governance service activities, strive to solve social problems, and work together to promote the realization of the Chinese Dream of the great rejuvenation of the Chines nation.

Thirdly, to consolidate and develop the patriotic united front in the new era, unite all forces that can be united, hold high the banner of patriotism and socialism, firmly establish the theme of great unity and great coalition, find the greatest common divisor of building the Chinese Dream, and draw the greatest concentric circle. [7]

On the one hand, it is necessary to strengthen the construction of multi-party cooperation and political consultation system under the leadership of the Communist Party of China and promote deliberative democracy. It is necessary to develop socialist democratic politics, further standardize and improve the content and form of the political consultation system, standardize the consultation procedures, conduct deliberative democracy and democratic supervision throughout the entire process of political consultation, democratic supervision, and participation in the administration and discussion of state affairs, clarify the connotation, scope, and field of democratic supervision, support the democratic parties to strengthen their own construction by strengthening their ideological, organizational, and institutional construction, and participate in the process of the great rejuvenation of the Chinese nation.

On the other hand, the national unity and progress education shall be deepened to increase consensus, promote unity, and build a community consciousness of 56 nationalities building the Chinese dream together. Commendation and publicity shall be conducted on individuals, collectives and related organizations that are involved in national unity and progress. The religious work in the new era shall be conducted well to guide religious people to serve the socialist modernization and the great rejuvenation of the Chinese nation.

Lastly, the exchange and visit mechanism between Hong Kong, Macao and Taiwan youth and social groups shall be continuously built and deepened. It is feasible to organize Hong Kong, Macao and Taiwan youth summer camp activities, launch the Chinese culture forum, and promote exchanges and communications between Hong Kong, Macao and Taiwan students and social groups. At the same time, based on the international and domestic overall situations, to do a good job in the united front work in the new era, actively participate in the "Belt and Road" to build a "human destiny community" to practice the united front, create good external conditions for the realization of the Chinese Dream, and promote the realization of Chinese Dream as soon as possible.

\section{Conclusion}

The essence of united front work is the great unity and great coalition. Looking at the important role of the united front in the struggle of the Chinese Communist Party for more than 90 years, to realize the Chinese Dream of the great rejuvenation of the Chinese nation in 2050, it is necessary to strengthen the party's political and organizational leadership over the united front in the new era, constantly advance with the times, strengthen the building of the party's united front, and continuously expand the scope, space and object of the united front alliance in the new era. At the same time, it is required to actively carry forward the fine style of our party, unite and coordinate party organizations at all levels, democratic parties, people's organizations, all socialist laborers, builders of socialist undertakings, patriots who support socialism, patriots who support the reunification of the motherland and the patriots committed to the great rejuvenation of the Chinese nation, mobilize all positive factors, conscientiously implement the policies and regulations formulated by the party on the united front, give play to the cohesive force of the Chinese Dream in the united front work in the new era, and do a good job in the united front under the new situation, and struggle for the great rejuvenation of the Chinese nation. 


\section{Acknowledgement}

Fund Project: This work is the phased research result of school-level scientific research project in 2018 of Xi'an Peihua University. Project Name: Research on Measures to Promote the Realization of Chinese Dream by the United Front Ideology of Xi Jinping. Project No. PHKT18027.

\section{References}

[1] Xu Likun. Outline of Xi Jinping's United Front Ideology in the New Era [J]. Journal of Guangxi Institute of Socialism, 2018, 4, (2).

[2] Meng Hui. To Build the Chinese Dream together with United Front [J]. Journal of Tianjin Institute of Socialism, 2014, (01).

[3] To Promote the Institutionalization, Normalization and Scientification of United Front Work Six Focuses of the Communist Party of China United Front Work Regulations (Trial), http://www.zytzb.gov.cn/tzb2010/tiaoli/201505/d0d324e0bf56445fb37bad5b69a7f33e.shtml, 2015-05-26.

[4] Shi Min. 2. The United Front is an Effective Weapon for Realizing the Chinese Dream [J]. Journal of Tianjin Institute of Socialism, 2014, (04).

[5] [7] Editors. Introduction to Map Zedong Thought and the Theoretical System of Socialism with Chinese Characteristics (2018) [M]. Higher Education Press, 197-199, 218-219.

[6] The Communist Party of China United Front Work Regulations (Trial), http://politics.people.com.cn/n/2015/0923/c1001-27623257.html. 